Transitional justice: theories, mechanisms and debates / Hakeem O. Yusuf, Hugo van der Merwe (eds.). - London: Routledge, Taylor \& Francis Group, 2022 - xxi, 303S., Lit., Lit.Hinw. ISBN 978-1-138-79408-5; 978-1-138-79407-8

Tushnet, Mark V.: The new fourth branch: institutions for protecting constitutional democracy / Mark V. Tushnet. - Cambridge, UK: Cambridge University Press, 2021 - ix, 186S., Lit.Hinw. (Comparative constitutional law and policy) ISBN 978-1-00-904849-1; 978-1-316-51783-3

\title{
AFRIKA / AFRICA
}

Abrahamsen, Rita; Bareebe, Gerald: Uganda's fraudulent election / Rita Abrahamsen, Gerald Bareebe. - In: Journal of democracy (Baltimore, Md), 32 (2021) 2, S. 90-104

Adams, Rachel: Human rights and the Fourth Industrial Revolution in South Africa / Rachel Adams. Cape Town, South Africa: HSRC Press, 2021 - xxxvii, 168S., Lit. ISBN 978-0-7969-2609-8

Adeola, Romola: The Kampala Convention and the protection of persons internally displaced by harmful practices in Africa / Romola Adeola. - In: Journal of African law (Cambridge), 65 (2021) S1, S. 101-114, Lit.Hinw.

Adeola, Romola; Mezmur, Benyam D.: The protection of internally displaced children in Africa: a doctrinal analysis of article 23(4) of the African Children's Charter / Romola Adeola, Benyam D. Mezmur. - In: Journal of African law (Cambridge), 65 (2021) S1, S. 115-129, Lit.Hinw.

African governance, security, and development / Wanjala Shadrack Nasong'o (ed.). - Lanham: Lexington Books, 2021 - xxiii, 302S., Lit. ISBN 978-1-79364-558-6

Akech, Joseph Geng: Exacerbated inequalities: implications of COVID-19 for the socio-economic rights of women and children in South Sudan / Joseph Geng Akech. - In: African human rights law journal (Lansdowne), 20 (2020) 2, S. 584-606, Lit.Hinw.

Akinocho, Hervé; Adaba, Koffi Amessou: La liberté d'expression et la liberté de presse: ingrédients clés de la démocratie togolaise / Hervé Akinocho, Koffi Amessou Adaba. - Ghana: Afrobarometer, 2021 - [Elektronische Ressource (24S., Ill.)] (Afrobarometer Policy Paper; 76)

Bachmann, Klaus; Kemp, Gerhard: Was quashing the Maji-Maji uprising genocide? An evaluation of Germany's conduct through the lens of international criminal law / Klaus Bachmann, Gerhard Kemp. - In: Holocaust and genocide studies (Oxford), 35 (2021) 2, S. 235-249

Bashizi, Anuarite; Ansoms, An; Ndayikengurutse, Guillaume; Amani, Romuald Adili; Akilimali, Joël Baraka; Chiza, Christian; Karangwa, Innocent; Mobali, Laurianne; Mudinga, Emery Mushagalusa; Mutabesha, David; Niyonkuru, René-Claude; Nsabimana, Joseph; Bisoka, Aymar Nyenyezi; Piccoli, Emmanuelle: Real governance of the COVID-19 crisis in the Great Lakes region of Africa / Anuarite Bashizi, An Ansoms, Guillaume Ndayikengurutse, Romuald Amani, Joel Baraka Akilimali, Christian Chiza, Innocent Karangwa, Laurianne Mobali, Emery Mushagalusa Mudinga, David Mutabesha, René-Claude Niyonkuru, Joseph Nsabimana, Aymar Nyenyezi Bisoka, Emmanuelle Piccoli. - In: Journal of Eastern African studies (London), 15 (2021) 2, S. 190-213, Lit., Lit.Hinw.

Bishop, Michael: Asserting customary fishing rights in South Africa / Michael Bishop. - In: Journal of Southern African studies (Abingdon), 47 (2021) 2, S. 291-308, Lit.Hinw. 
Bolt, Maxim: Homeownership, legal administration, and the uncertainties of inheritance in South Africa's townships: Apartheid's legal shadows / Maxim Bolt. - In: African affairs (Oxford), 120 (2021) 479, S. 219-241

Boone, Catherine; Bado, Arsène Brice; Dion, Aristide Mah; Irigo, Zibo: Push, pull and push-back to land certification: regional dynamics in pilot certification projects in Côte d'Ivoire / Catherine Boone, Arsene Brice Bado, Aristide Mah Dion, Zibo Irigo. - In: The journal of modern African studies (London), 59 (2021) 3, S. 247-272, Kt.

Cheeseman, Nic; Matfess, Hilary; Amani, Alitalali: Tanzania: the roots of repression / Nic Cheeseman, Hilary Matfess, Alitalali Amani. - In: Journal of democracy (Baltimore, Md), 32 (2021) 2, S. $77-89$

Choi, Hyun Jin; Raleigh, Clionadh: The geography of regime support and political violence / Hyun Jin Choi, Clionadh Raleigh. - In: Democratization (Ilford, Essex), 28 (2021) 6, S. 1095-1114

Delius, Peter: Chiefly succession and democracy in South Africa: why history matters / Peter Delius. In: Journal of Southern African studies (Abingdon), 47 (2021) 2, S. 209-227, Ill., Lit.Hinw.

Deng, Francis Mading; Adeola, Romola: The normative influence of the UN Guiding Principles on the Kampala Convention in the protection of internally displaced persons in Africa / Francis Mading Deng, Romola Adeola. - In: Journal of African law (Cambridge), 65 (2021) S1, S. 59-72, Lit.Hinw.

The emergent African Union law: conceptualization, delimitation, and application / Olufemi Amao, Michèle Olivier, Kōnstantinos D. Magliveras (eds.). - Oxford: Oxford University Press, 2021 - xi, 483S., Lit.Hinw. ISBN 978-0-19-886215-4

Emiljanowicz, Paul; Ibhawoh, Bonny: Democracy in postcolonial Ghana: tropes, state power and the defence committees / Paul Emiljanowicza, Bonny Ibhawoh. - In: Third world quarterly (Abingdon), 42 (2021) 6, S. 1213-1232, graph. Darst.

Fombad, Charles Manga; Abdulrauf, Lukman Adebisi: Comparative overview of the constitutional framework for controlling the exercise of emergency powers in Africa / Charles Manga Fombad, Lukman Adebisi Abdulrauf. - In: African human rights law journal (Lansdowne), 20 (2020) 2, S. 376-411, Lit.Hinw.

Goldsmith, Arthur Austin: Political regimes and foreign investment in poor countries: insights from most similar African cases / Arthur Austin Goldsmith. - In: European journal of international relations (London), 27 (2021) 3, S. 804-807, graph. Darst., Tab.

Gubaye, Assaye Alamineh; Anteneh, Kumilachew Siferaw; Dinberu, Abebe Dires; Ali, Mohammed Seid: The nexus between shimglina as ADR and the formal criminal justice system: the case of the Amhara regional state, Ethiopia / Gubaye Assaye Alamineh, Kumilachew Siferaw Anteneh, Abebe Dires Dinberu, Mohammed Seid Ali. - In: African journal on conflict resolution (Mt. Edgecombe), 21 (2021) 1, S. 141-159, Lit. S. 158-159, Lit.Hinw.

Gyimah-Boadi, E.; Logan, Carolyn; Appiah-Nyamekye, Josephine: Africans' durable demand for democracy / E. Gyimah-Boadi, Carolyn Logan, Josephine Appiah-Nyamekye. - In: Journal of democracy (Baltimore, Md), 32 (2021) 3, S. 136-151, graph. Darst. 
Hazoumê, Marc-Laurent: Bénin: rupture : destructuration de l'esprit de la Conférence nationale ou conjuration de la fatalité? / Marc-Laurent Hazoumê. - Paris: L'Harmattan, 2021 - 133S., Lit. S. 131-132 (Études africaines. Série Politique) ISBN 978-2-343-22648-4

Hubrecht, Joël: Une longue errance: la justice française et la "complicité de génocide" au Rwanda / Joël Hubrecht. - In: Esprit (Paris), (2021) 478, S. 65-76

Ifediora, Obinna F.: Formulative strategy: why the African Union-led international mediation in South Sudan failed to prevent atrocity crimes / Obinna F. Ifediora. - In: International studies perspectives (Oxford), 22 (2021) 3, S. 301-320, Lit. S. 318-320

Iroulo, Lynda Chinenye: A weapon of the weak: fighting police brutality through social media / Lynda Chinenye Iroulo. - Hamburg: German Institute for Global and Area Studies (GIGA), 2021 [Elektronische Ressource (12S., Lit.)] (GIGA Focus Africa; 2021/6)

Justice française et génocide des Tutsi au Rwanda / Jean-François Boudet (ed.). - Paris: L'Harmattan, 2021 - 401S. (Droits, sociétés, politiques Afrique des Grands Lacs) ISBN 978-2-343-22848-8

Kaaba, O'Brian; Hinfelaar, Marja; Zhou, Tony: Comparing legal activism in Zimbabwe and Zambia / O'Brien Kaaba, Marja Hinfelaar, Tony Zhou. - Bergen, Norway: Chr. Michelsen Institute, 2020 - [Elektronische Ressource (29S., Lit., Lit.Hinw.)] (CMI working paper; 5) ISBN 978-82-8062-763-6

Kabira, Nkatha: Saving the soul of an African constitution: learning from Kenya's experience with constitutionalism during COVID-19 / Nkatha Kabira. - In: African human rights law journal (Lansdowne), 20 (2020) 2, S. 436-461, Lit.Hinw.

Kampire, Pamela: The impact of the COVID-19 pandemic on gender-based violence in Uganda: a policy review and analysis / Pamela Kampire. - Hamburg: German Institute for Global and Area Studies (GIGA), September 2021 - [Elektronische Ressource (22S., Lit. S. 20-22)] (COVID-19 gender-based violence policy tracker working paper; 2)

Konečná, Lucie; Mrva, David: Refugee-related political violence in Asia and Africa / Lucie Konečná, David Mrva. - In: Central European journal of international and security studies (Prague). 15 (2021) 3, S. 55-76, graph. Darst., Ill., Lit.Hinw. S. 75-76

Land, law and chiefs in rural South Africa: contested histories and current struggles / William Beinart, Rosalie Kingwill, Gavin Capps (eds.). - Johannesburg: Wits University Press, 2021 - xii, 282S., Lit. ISBN 978-1-77614-680-2; 978-1-77614-679-6

Leininger, Julia; Nowack, Daniel: Protecting democracy: the relevance of international democracy promotion for term limits / Julia Leininger, Daniel Nowack. - Bonn: Deutsches Institut für Entwicklungspolitik, 2021 - [Elektronische Ressource (4S., Ill.)] (Briefing paper; 2021/21)

Lim, Woojin: Assessing the implications of digital contact tracing for COVID-19 for human rights and the rule of law in South Africa / Woojin Lim. - In: African human rights law journal (Lansdowne), 20 (2020) 2, S. 540-557, Lit.Hinw.

Mbikiwa, Michael: Towards living customary administrative law / Michael Mbikiwa. - In: Journal of Southern African studies (Abingdon), 47 (2021) 2, S. 251-272, Lit.Hinw. 
Mohamed, Zaheda: South Africa: policy effort on violence against women and children/domestic violence before and since COVID-19 / Zaheda Mohamed. - Hamburg: German Institute for Global and Area Studies (GIGA), October 2021 - [Elektronische Ressource (20S., Lit. S. 17-20)] (COVID-19 gender-based violence policy tracker working paper; 3)

Nhlapo, Ronald Thandabantu: Customary marriage: missteps threaten the constitutional ideal of common citizenship / Ronald Thandabantu Nhlapo. - In: Journal of Southern African studies (Abingdon), 47 (2021) 2, S. 273-289, Lit.Hinw.

Nkhata, Mwiza Jo; Mwenifumbo, Anganile Willie: Livelihoods and legal struggles amidst a pandemic: the human rights implications of the measures adopted to prevent, contain and manage COVID-19 in Malawi / Mwiza Jo Nkhata, Anganile Willie Mwenifumbo. - In: African human rights law journal (Lansdowne), 20 (2020) 2, S. 512-539, Lit.Hinw.

Nkuubi, James: When guns govern public health: examining the implications of the militarised COVID-19 pandemic response for democratisation and human rights in Uganda / James Nkuubi. In: African human rights law journal (Lansdowne), 20 (2020) 2, S. 607-639, Lit.Hinw.

Palacios-Arapiles, Sara: Unfolding Africa's impact on the development of international refugee law / Sara Palacios-Arapiles. - In: Journal of African law (Cambridge), 65 (2021) S1, S. 9-33, Lit.Hinw.

Paulson-Smith, Kaden; Tripp, Aili Mari: Women's rights and critical junctures in constitutional reform in Africa (1951-2019) / Kaden Paulson-Smith, Aili Mari Tripp. - In: African affairs (Oxford), 120 (2021) 480, S. 365-389, graph. Darst.

Sahin, Bilge: Mobile hearings in the Eastern DRC: prosecuting international crimes and implementing complementarity at national level / Bilge Sahin. - In: Journal of Eastern African studies (London), 15 (2021) 2, S. 297-316, Lit., Lit.Hinw.

Shale, Itumeleng: Implications of Lesotho's COVID-19 response framework for the rule of law / Itumeleng Shale. - In: African human rights law journal (Lansdowne), 20 (2020) 2, S. 462-483, Lit.Hinw.

Shongwe, Musa Njabulo: Eswatini's legislative response to COVID-19: whither human rights? / Musa Njabulo Shongwe. - In: African human rights law journal (Lansdowne), 20 (2020) 2, S. 412-435, Lit.Hinw.

Souza Louw, Monica de: Finding roles in unseen places: government action conferring roles on traditional authorities in South Africa / Monica de Souza Louw. - In: Journal of Southern African studies (Abingdon), 47 (2021) 2, S. 229-250, Lit.Hinw.

Staden, Martin van: Constitutional rights and their limitations: a critical appraisal of the COVID-19 lockdown in South Africa / Martin van Staden. - In: African human rights law journal (Lansdowne), 20 (2020) 2, S. 484-511, Lit.Hinw.

Ubink, Janine Marisca; Duda, Thiyane: Traditional authority in South Africa: reconstruction and resistance in the Eastern Cape / Janine Ubink, Thiyane Duda. - In: Journal of Southern African studies (Abingdon), 47 (2021) 2, S. 191-208, Lit.Hinw.

Wicomb, Wilmien: The in-between world of Kgosi Nyalala Pilane: (mis)appropriation and accountability among the Bakgatla-Ba-Kgafela in 21st-century South Africa / Wilmien Wicomb. - In: Journal of Southern African studies (Abingdon), 47 (2021) 2, S. 173-190, Lit.Hinw. 